\title{
Occurrence of Antimicrobials in River Water Samples from Rural Region of the State of Rio de Janeiro, Brazil
}

\author{
Mychelle Alves Monteiro ${ }^{1,2 *}$, Bernardete Ferraz Spisso², \\ Julia Rodrigues Martins Pastor dos Santos ${ }^{2}$, Rafaela Pinto da Costa ${ }^{2}$, \\ Rosana Gomes Ferreira2, Mararlene Ulberg Pereira2, \\ Talita da Silva Miranda ${ }^{3}$, Bárbara Rodrigues Geraldino de Andrade4, \\ Luiz Antonio d'Avila ${ }^{1}$ \\ ${ }^{1}$ Chemistry School/Federal University of Rio de Janeiro (EQ/UFRJ), Rio de Janeiro, Brazil \\ ${ }^{2}$ National Institute for Quality Control in Health/Oswaldo Cruz Foundation (INCQS/FIOCRUZ), Rio de Janeiro, \\ Brazil \\ ${ }^{3}$ University Centre of Barra Mansa (UBM), Barra Mansa, Brazil \\ ${ }^{4}$ National of Institute of Cancer (INCA), Rio de Janeiro, Brazil \\ Email: "mychelle.monteiro@incqs.fiocruz.br
}

Received 19 January 2016; accepted 22 February 2016; published 25 February 2016

Copyright (C) 2016 by authors and Scientific Research Publishing Inc.

This work is licensed under the Creative Commons Attribution International License (CC BY). http://creativecommons.org/licenses/by/4.0/

\section{(c) (i) Open Access}

\section{Abstract}

The occurrence of antimicrobials in the aquatic environment and drinking water has raised the question of their impact on the environment and public health. Animal production is one of the most expressive activities of Brazilian agribusiness. In order to ensure the productivity and competitiveness of the sector, the use of drugs for therapeutic and prophylactic purposes is a common practice. Due to the continuous release of antimicrobials into the environment, the aim of this study was to compare the frequency of detection of tetracyclines and sulfonamides in surface water collected from rural areas in Lidice District of Rio Claro, in the State of Rio de Janeiro, Brazil. An investigative study was conducted with 24 river water samples analyzed by high-performance liquid chromatography coupled to tandem mass spectrometry and the aim of this study was to determine residues of sulfonamides and tetracyclines based on the USEPA method 1694. The results indicated the presence of sulfamethoxazole and oxytetracycline concentrations at the $\mathrm{ng} \cdot \mathrm{L}^{-1}$ level. The applied method showed overall good performance with recoveries above $57 \%$, method detection limits $\leq 7.17 \mathrm{ng} \cdot \mathrm{L}^{-1}$, method quantification limits $\leq 23.90$ ng. $\mathrm{L}^{-1}$ and good linearity.

\footnotetext{
${ }^{*}$ Corresponding author.
} 


\section{Keywords}

\section{Antimicrobial, LC-MS/MS, Surface Water, Sulfonamides, Tetracyclines}

\section{Introduction}

Animal production is one of the most expressive activities of Brazilian agribusiness. In order to ensure the productivity and competitiveness of the sector, the use of drugs for therapeutic and prophylactic purposes is a common practice. Concerning the drugs employed, the antimicrobial agents correspond to one of the most widely prescribed classes [1]-[7]. Antimicrobials are drugs used in human and veterinary medicine. They are applied as growth promoters and for therapeutic or prophylactic purposes [2]. Therefore, several classes, as aminoglycosides, $\beta$-lactams, fluoroquinolones, lincosamides, macrolides, tetracyclines and sulfonamides are widely used in veterinary medicine [8] [9].

There are several possible sources and routes for the occurrence of antimicrobials in the aquatic environment. As regards to human use antimicrobials, non-prescribed medicines are consumed at home, and other prescribed are consumed in hospitals and clinics. These drugs are metabolized and excreted partly in urine and faeces, then go to the sewage collection systems. Unused or surplus medicines, or out of date, can be discarded of in toilets, although this practice is not currently recommended. Hospital effluents can be treated separately or combined with municipal wastewater and then treated in wastewater treatment plants (WWTP). The consumption of veterinary antibiotics is held on farms, veterinary clinics and at home to treat pets [10]. There is a great difficulty in predicting the possible implications of the presence of antimicrobials in water and sewage, regarding to the environment and public health. Furthermore, some drugs such as antidepressants and antimicrobials may be prone to bioconcentration and bioaccumulation in aquatic organisms, particularly fish. Therefore, the presence of pharmaceuticals in environmental waters, especially in drinking water and pharmaceuticals industries effluents should be considered an important issue in terms of safety of human health [11].

Different adverse effects of pharmaceutical compounds have been described including aquatic toxicity, development of resistance in pathogenic bacteria, genotoxicity and endocrine disorders [12]-[14].

Several substances have attracted attention because of their impact on the environment, especially in aquatic one, due to their high stability and toxicity. Water treatment systems are not very effective to degrade this substance, which is an extremely important requirement for disposing such waste, preventing the risk of environment contamination [11] [15].

The integrity of human and environmental health is closely related to a good sanitation and health of the waters. According to the World Health Organization (WHO), about 85\% of known diseases are waterborne, or are associated with water [16].

Pharmaceuticals compounds are present at low level ranging from ng $\cdot \mathrm{L}^{-1}$ to $\mu \mathrm{g} \cdot \mathrm{L}^{-1}$. A large number of analytical methodologies have been developed for the determination of antimicrobials residues in surface waters [17].

Sulfonamides (SF) are inexpensive antimicrobial used to treat bacterial infections with a broad spectrum of activity, employed in human and veterinary medicine [7]. Tetracyclines (TC) are widely used in veterinary medicine for both prophylactic and therapeutic purposes in food producing animals, besides in humans [2].

Several veterinary drug residue monitoring programs have been conducted worldwide, and sulfonamide and tetracycline residues have been detected in food of animal origin, proving the use of these drugs in veterinary medicine [18].

The aim of this study was to determine residues of sulfonamides and tetracyclines based on the United States Environmental Protection Agency-USEPA 1694 [19]. USEPA Method 1694 is intended to determine pharmaceuticals and personal care products (PPCPs) in environmental samples (aqueous, solid and biosolids matrices) by high performance liquid chromatography combined with tandem mass spectrometry (HPLC/MS/MS) using isotope dilution and internal standard quantitation techniques. 24 Surface water samples were collected from two rivers (Parado and Pedras) in the Lidice District of Rio Claro, in the state of Rio de Janeiro, Brazil, in August 2014 (Figure 1). The method was able to determine 14 analytes from tetracycline and sulfonamide classes: chlortetracycline, demeclocycline, doxycycline, metacycline, oxytetracycline, tetracycline, dapsone, sulfacetamide, sulfadimethoxin, sulfamerazine, sulfamethazine, sulfamethoxazole, sulphaquinoxaline and sulfathiazole. 


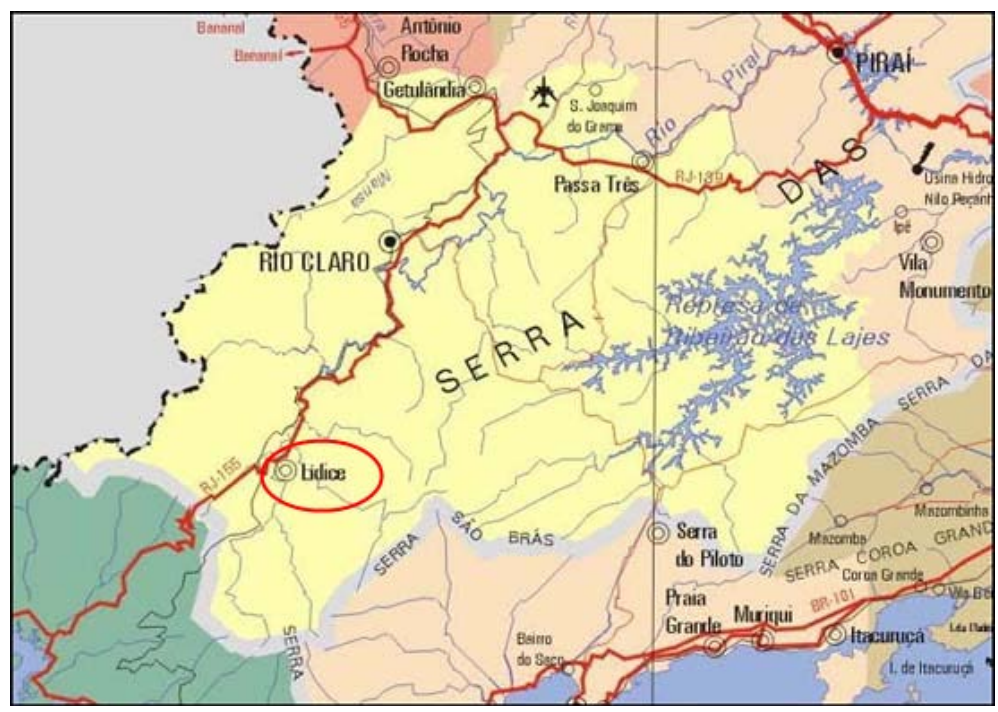

Figure 1. Water map of Rio Claro city, in the State of Rio de Janeiro, highlighting Lidice District. Source: Rio Claro geography [20].

\section{Material and Methods}

\subsection{Chemicals and Materials}

Methanol (MeOH) for liquid chromatography was purchased from J.T. Baker (Phillipsburg, NJ, USA). LCgrade acetonitrile (ACN) and reagent grade hydrochloric acid, oxalic acid (OXA), formic acid (FOA) and acetone (ACE) were purchased from Merck (Darmstadt, Germany). Ethylenediaminetetracetic acid disodium dihydrate (EDTA) was acquired from Calbiochem (Gibbstown, NJ, USA). Ultrapure water was obtained from a Milli-Q purification system (Millipore, Bedford, MA, USA). Certified reference standards of oxytetracycline, doxycycline hyclate and hydrochloride salts of chlortetracycline, demeclocycline, dapsone, sulfacetamide, sulfadimethoxin, sulfamerazine, sulfamethazine, sulfamethoxazole, sulphaquinoxaline and sulfathiazole were available from US. Pharmacopeial Convention (Rockville, MD, USA). Tetracycline hydrochloride was a Chemical Reference Substance of the Brazilian Pharmacopeial Convention (Santa Maria, RS, Brazil). Methacycline was acquired from Acros (Pittsburgh, PA, USA).

Solid-phase extraction (SPE) was performed with 60 mg Oasis ${ }^{\circledR}$ HLB cartridges from Waters Corp. (Milford, MA, USA).

\subsection{Sample Collection and Preparation}

$300 \mathrm{~mL}$ of each water samples were collected in polypropylene bottles during three consecutive Sundays (17, 24 and 31 August 2014), in the morning and in the afternoon, in the upper and lower sides of each river (two sampling points), a total of eight samples per day collection, according to the Table 1. Grab sampling procedures were applied in study. The lengths of the rivers Parado and Pedras are respectively $10 \mathrm{~km}$ and $13 \mathrm{~km}$.

The 24 samples were sealed, identified and transported under refrigeration to the laboratory for performing analyses. An aliquot of $100 \mathrm{~mL}$ of the each sample was acidified to $\mathrm{pH} 2.5$ with $\mathrm{HCl}$, and then $100 \mathrm{mg}$ of EDTA was added. $25 \mathrm{~mL}$ of this solution was applied to an Oasis $\mathrm{HLB}^{\circledR}$ cartridge previously conditioned with $3 \mathrm{~mL}$ of $\mathrm{MeOH}, 3 \mathrm{~mL}$ of ultrapure water and $3 \mathrm{~mL}$ of ultrapure water acidified to $\mathrm{pH} 2.5$ with $\mathrm{HCl}$. A manifold vacuum from Alltech (Deerfield, IL, USA) was used for SPE. Cartridges were washed twice with $2 \mathrm{~mL}$ of ultrapure water and then dried under vacuum $(-35 \mathrm{kPa})$ for $2 \mathrm{~min}$. Antimicrobials were eluted with two portions of $2 \mathrm{~mL}$ methanol and two portions of $2 \mathrm{~mL}$ ACE:MeOH (1:1, v/v), using gravity flow only. $1 \mathrm{~mL}$ aliquots of the eluate were transferred to two centrifuge tubes and evaporated to dryness under $\mathrm{N}_{2}$ in a temperature up to $47.5^{\circ} \mathrm{C}$, using an evaporator with nitrogen flow (Pierce Reacti-Therm III $^{\mathrm{TM}}$ and Pierce Reacti Vap ${ }^{\mathrm{TM}}$ III, Rockford, IL, USA).

The dry residues were reconstituted with $1 \mathrm{~mL}$ of $0.01 \mathrm{~mol} \cdot \mathrm{L}^{-1}$ OXA:MeOH $(80: 20, \mathrm{v} / \mathrm{v})$ for tetracycline analysis and $1 \mathrm{~mL}$ of $0.01 \mathrm{~mol} \cdot \mathrm{L}^{-1}$ FOA:MeOH $(80: 20, \mathrm{v} / \mathrm{v})$ for sulfonamide analysis, vortexed for $30 \mathrm{~s}$ and 
Table 1. Sample collection.

\begin{tabular}{lcccc}
\hline & \multicolumn{2}{c}{ Pedras River } & \multicolumn{2}{c}{ Parado River } \\
\hline & Upper Side & Lower Side & Upper Side & Lower Side \\
\hline Morning & 3 per day & 3 per day & 3 per day & 3 per day \\
Afternoon & 3 per day & 3 per day & 3 per day & 3 per day \\
Total samples in 3 consecutive days & 6 & 6 & 6 & 6 \\
\hline
\end{tabular}

transferred to amber auto-sampler vials for the injection of $10 \mu \mathrm{L}$ (TC) and $20 \mu \mathrm{L}$ (SF) [3] [7].

In order to calculate method recoveries, $25 \mathrm{~mL}$ of a solution at $100 \mathrm{ng} \cdot \mathrm{L}^{-1}$ (TC and SF) and $25 \mathrm{~mL}$ of ultrapure water were used. Ultrapure water samples were spiked post-extraction and reconstituted with $1 \mathrm{~mL}$ of 100 $\mathrm{ng} \cdot \mathrm{L}^{-1}$ solutions (TC and SF) prepared in the respective dilution solvents, $0.01 \mathrm{~mol} \cdot \mathrm{L}^{-1} \mathrm{OXA}: \mathrm{MeOH}(80: 20, \mathrm{v} / \mathrm{v})$ for tetracycline analysis and $1 \mathrm{~mL}$ of $0.01 \mathrm{~mol} \cdot \mathrm{L}^{-1} \mathrm{FOA}: \mathrm{MeOH}(80: 20, \mathrm{v} / \mathrm{v})$ for sulfonamide analysis. Six point calibration curves in the range of $78 \mathrm{ng} \cdot \mathrm{L}^{-1}$ to $780 \mathrm{ng} \cdot \mathrm{L}^{-1}$ were constructed and fitted by weighted regression analysis using a factor of $1 / \mathrm{x}^{2}$ and were performed in order to quantify the analytes. Recovery corrections were applied in all samples for quantification.

\subsection{LC/MS-MS Instrumentation}

The LC-MS/MS system was a Shimadzu Prominence HPLC instrument (Kyoto, Japan) equipped with a quaternary pump (LC-20AD), a membrane degasser (DGU-20A5), an auto-sampler (SIL-20AC), a column oven (CTO-20AC) and a system controller (CBM-20A) interfaced to a triple quadrupole mass spectrometer (API5000, Applied Biosystems/MDS Sciex, Foster City, CA, USA) with a TurboIonSpray ${ }^{\circledR}$ ESI source. Analyst ${ }^{\circledR}$ V1.4.2 $\mathrm{LC} / \mathrm{MS}$ control software was used. Maintained at $0.15 \mathrm{~mL} \cdot \mathrm{min}^{-1}$ at $25^{\circ} \mathrm{C}$. The autosampler was set at $4^{\circ} \mathrm{C}$. Positive electrospray ionization technique (ESI+) in Multiple Reaction Monitoring (MRM) acquisition mode was used to monitoring three ions for each substance. Nitrogen was employed as nebulizer and dryer gas (Gas 1 and Gas $2=40$ psi), collision-activated dissociation (CAD) gas (6, arbitrary unit) and Curtain ${ }^{\mathrm{TM}}$ gas (10 psi). Other parameters selected during automatic tuning were: ionspray potential $=5000 \mathrm{~V}$, source temperature $=500^{\circ} \mathrm{C}$, entrance potential $=10 \mathrm{~V}$, resolution Q1 and Q3 = unit, dwell time of $150 \mathrm{~ms}$ for each MRM transition. The analytical column was a Pursuit ${ }^{\mathrm{TM}}$ RS C18 $(100 \mathrm{~mm} \times 2 \mathrm{~mm}$ id, $3 \mu \mathrm{m}$ particle size, $200 \AA$ ), with a respective guard column (Agilent, Santa Clara, CA, USA). Mobile phases A, B and C consisted of $\mathrm{H}_{2} \mathrm{O}$, ACN and $\mathrm{MeOH}$, all of them with $0.1 \%$ FOA. Gradient elution programs were carried out for separating the antimicrobials, as described in Table 2 [3] [7]. Column temperatures and injection volumes are also described in Table 2.

Multiple Reaction Monitoring (MRM) experiments for tetracycline analysis in electrospray positive-ion mode (ESI+) were described by Spisso et al. [3] and the employed conditions are listed in Table 3.

Fragmentation studies with sulfonamides for tuning the mass spectrometer were performed with mixed standard solutions at concentrations between 50 and $100 \mathrm{ng} \cdot \mathrm{mL}^{-1}$ in MeOH: $1 \%$ FOA (50:50, v/v). ESI+ in MRM acquisition mode was used to monitor three ions for each substance.

\section{Results and Discussion}

\subsection{Mass Spectrometry Conditions}

Optimizing the mass spectrometer detection consists of adjusting several parameters relating to both ionization process in the ion source and ion transportation in the MS in order to maximize the response of the mass spectrometer for each analyte. MRM acquisition mode is the most suitable for quantification due to its sensitivity and specificity. Declustering Potential (DP), Collision Energy (CE) and Collision Cell Exit Potential (CXP) values for sulfonamide precursor/product ion pairs obtained in MRM mode are showed in Table 3. For sulfonamides, only protonated molecules $[\mathrm{M}+\mathrm{H}]^{+}$were observed and selected as precursor ions, and no adducts were noted. The three most abundant fragment ions were monitored for each compound. For target analytes, the first transition was used for quantification purposes, whereas the second and the third ones to confirm the identity of the substances.

SFs showed a standard mass spectrum, due to the presence, in their structure, of a heterocycle attached to the 
Table 2. Gradient elution programs for Sulfonamides (SF) and Tetracyclines (TC).

\begin{tabular}{|c|c|c|c|c|c|c|c|c|c|}
\hline \multirow[b]{2}{*}{$\begin{array}{l}\text { Time } \\
(\mathrm{min})\end{array}$} & \multicolumn{4}{|c|}{ TC Method } & \multicolumn{5}{|c|}{ SF Method } \\
\hline & $\% \mathrm{~A}$ & $\%$ B & $\% \mathrm{C}$ & $\begin{array}{l}\text { Flow rate } \\
\left(\mathrm{mL} \cdot \mathrm{min}^{-1}\right)\end{array}$ & $\begin{array}{l}\text { Time } \\
\text { (min) }\end{array}$ & $\% \mathrm{~A}$ & $\%$ B & $\% \mathrm{C}$ & $\begin{array}{l}\text { Flow rate } \\
\left(\mathrm{mL} \cdot \mathrm{min}^{-1}\right)\end{array}$ \\
\hline 1 & 80 & 5 & 15 & 0.15 & 1 & 80 & 5 & 15 & 015 \\
\hline 15 & 60 & 25 & 15 & 0.15 & 15 & 60 & 25 & 15 & 0.15 \\
\hline 16 & 5 & 5 & 90 & 0.15 & 16 & 5 & 5 & 90 & 0.25 \\
\hline 26 & 5 & 5 & 90 & 0.15 & 20 & 5 & 5 & 90 & 0.25 \\
\hline 27 & 80 & 5 & 15 & 0.15 & 26 & 5 & 5 & 90 & 0.15 \\
\hline 35 & 80 & 5 & 15 & 0.15 & 27 & 15 & 5 & 15 & 0.15 \\
\hline- & - & - & - & - & 35 & 15 & 5 & 15 & 0.15 \\
\hline $\begin{array}{l}\text { Column } \\
\text { temperature }\end{array}$ & \multicolumn{4}{|c|}{$15^{\circ} \mathrm{C}$} & \multicolumn{5}{|c|}{$25^{\circ} \mathrm{C}$} \\
\hline Injection Volume & \multicolumn{4}{|c|}{$10 \mu \mathrm{L}$} & \multicolumn{5}{|c|}{$20 \mathrm{~L}$} \\
\hline
\end{tabular}

sulfonamide moiety. The fragmentation scheme of protonated sulfonamides in positive-ion ESI has already been described in the literature and was characterized by m/z $92\left[\mathrm{H}_{2} \mathrm{NPhenyl}\right]^{+}, \mathrm{m} / \mathrm{z} 108\left[\mathrm{H}_{2} \mathrm{NPhenylO}^{+}, \mathrm{m} / \mathrm{z} 156\right.$ $\left[\mathrm{H}_{2} \mathrm{NPhenylSO}_{2}\right]^{+}$, besides $[\mathrm{M}+\mathrm{H}-93]^{+}$and $[\mathrm{M}+\mathrm{H}-66]^{+}[21]$.

All of the sulfonamides studied exhibited m/z 156 ion, except for sulfamethazine. The m/z 92 ion, although described in the literature, was not identified in the present study [21]-[25]. USEPA 1694 method did not present $\mathrm{m} / \mathrm{z} 92$ ion, but since only a single transition was used, it is not possible to conclude if it was not identified during the method development. Sulfamethazine spectrum showed m/z 204 ion which was also described by Verzegnassi et al. [21] for sulfadimidine corresponding to the fragment $\left[\mathrm{M}+\mathrm{H}-93+\mathrm{H}_{2} \mathrm{O}\right]^{+}$. Since both substances have the same molecular weight, we concluded that the observed m/z 204 ion had the same identity.

\subsection{LC Method Development}

Two chromatographic gradients were employed, one for sulfonamides and another for tetracyclines. USEPA Method 1694 guidelines establishes that any chromatographic gradient may be applied for the separation of the pharmaceutical compounds as long as the last eluting peak has a retention time greater than that obtained in the standard USEPA method [19] [24]. Gradient elution for chromatographic separation of tetracyclines was the same described by Spisso et al. [3]. For sulfonamide separation, another gradient was developed based on that employed for tetracyclines, due to the physicochemical similarities. A reversed phase gradient using a C18 analytical column with $3 \mu \mathrm{m}$ particles and mobile phases consisted of $\mathrm{H}_{2} \mathrm{O}, \mathrm{ACN}$ and $\mathrm{MeOH}$, all with $0.1 \% \mathrm{FOA}$, was developed, as described in Table 3, and all of the sulfonamides showed a good chromatographic peak resolution and eluted in a total time of $16 \mathrm{~min}$. In this method, tetracyclines elute up to $20.3 \mathrm{~min}$ and sulfonamides up to $15.2 \mathrm{~min}$, whereas in the USEPA Method 1694 tetracyclines elute in a total time of $16.7 \mathrm{~min}$ and sulfonamides in $13.2 \mathrm{~min}$.

\subsection{River Water Analysis}

Method recoveries were determined by analyzing samples of ultrapure water spiked in triplicate at $100 \mathrm{ng} \cdot \mathrm{L}^{-1}$. Recoveries were in the range of 57\% - 92\% and were similar to those described for USEPA 1694 method [19]. Recovery values with relative standard deviation (RSD) are reported in Table 3 as well as method detection limits (MDL), method quantification limits (MQL) and regression coefficients $\left(\mathrm{R}^{2}\right)$ of calibration curves were constructed in the range of $78 \mathrm{ng} \cdot \mathrm{L}^{-1}$ to $780 \mathrm{ng} \cdot \mathrm{L}^{-1}$. Comparing average concentrations obtained for each compound in the present study with average concentrations of USEPA 1694 method [19], all detected antimicrobials showed similar values, except for dapsone, sulfacetamide and sulphaquinoxaline that are not present in USEPA method. MDLs calculated for surface water were from 0.57 to $7.17 \mathrm{ng} \cdot \mathrm{L}^{-1}$ and MQLs ranged from approximately 1.73 to $23.90 \mathrm{ng} \cdot \mathrm{L}^{-1}$. 
Table 3. LC-MS/MS conditions for tetracyclines and sulfonamides.

\begin{tabular}{|c|c|c|c|c|c|c|}
\hline Substance & $\begin{array}{l}\text { Retention Time } \\
\text { (min) }\end{array}$ & $\begin{array}{c}\text { Precursor Ion } \\
(m / z)\end{array}$ & Product Ion $(m / z)$ & DP (volts) & CE (volts) & CXP (volts) \\
\hline & & & 444.00 & & 29 & 16 \\
\hline \multirow[t]{3}{*}{ Chlortetracycline } & 17.65 & 479.23 & 462.01 & 121 & 23 & 16 \\
\hline & & & 154.00 & & 39 & 14 \\
\hline & & & 448.10 & & 25 & 16 \\
\hline \multirow[t]{3}{*}{ Demeclocycline } & 14.75 & 465.21 & 430.10 & 106 & 33 & 16 \\
\hline & & & 289.10 & & 45 & 22 \\
\hline & & & 428.10 & & 27 & 16 \\
\hline \multirow[t]{3}{*}{ Doxycycline } & 20.30 & 445.31 & 321.20 & 96 & 43 & 12 \\
\hline & & & 154.20 & & 41 & 12 \\
\hline & & & 426.10 & & 25 & 16 \\
\hline \multirow[t]{3}{*}{ Metacycline } & 19.45 & 443.26 & 201.10 & 126 & 49 & 16 \\
\hline & & & 145.20 & & 75 & 16 \\
\hline & & & 426.20 & & 29 & 34 \\
\hline \multirow[t]{3}{*}{ Oxytetracycline } & 10.92 & 461.20 & 443.40 & 52 & 19 & 32 \\
\hline & & & 444.00 & & 21 & 16 \\
\hline & & & 410.10 & & 27 & 16 \\
\hline \multirow[t]{3}{*}{ Tetracycline } & 11.90 & 445.27 & 427.10 & 126 & 19 & 14 \\
\hline & & & 154.20 & & 37 & 12 \\
\hline & & & 156.00 & & 21 & 20 \\
\hline \multirow[t]{3}{*}{ Dapsone } & 7.64 & 249.30 & 108.10 & 156 & 31 & 12 \\
\hline & & & 110.20 & & 37 & 14 \\
\hline & & & 156.10 & & 15 & 16 \\
\hline \multirow[t]{3}{*}{ Sulfacetamide } & 3.40 & 215.14 & 108.00 & 71 & 29 & 14 \\
\hline & & & 110.00 & & 33 & 16 \\
\hline & & & 156.30 & & 29 & 10 \\
\hline \multirow[t]{3}{*}{ Sulfadimethoxine } & 14.66 & 311.16 & 108.10 & 141 & 41 & 14 \\
\hline & & & 245.20 & & 27 & 16 \\
\hline & & & 108.20 & & 37 & 10 \\
\hline \multirow[t]{3}{*}{ Sulfamerazine } & 4.85 & 265.25 & 156.20 & 96 & 25 & 10 \\
\hline & & & 110.20 & & 35 & 10 \\
\hline & & & 124.10 & & 37 & 16 \\
\hline \multirow[t]{3}{*}{ Sulfamethazine } & 6.44 & 279.21 & 204.10 & 111 & 25 & 16 \\
\hline & & & 108.20 & & 41 & 12 \\
\hline & & & 156.10 & & 23 & 16 \\
\hline \multirow[t]{3}{*}{ Sulfamethoxazole } & 10.50 & 254.18 & 108.20 & 116 & 33 & 14 \\
\hline & & & 147.20 & & 23 & 22 \\
\hline & & & 156.10 & & 25 & 22 \\
\hline \multirow[t]{3}{*}{ Sulphaquinoxaline } & 15.23 & 301.34 & 108.10 & 141 & 39 & 12 \\
\hline & & & 146.20 & & 33 & 14 \\
\hline & & & 156.10 & & 21 & 16 \\
\hline \multirow[t]{2}{*}{ Sulfathiazole } & 4.21 & 256.30 & 108.10 & 91 & 33 & 16 \\
\hline & & & 101.10 & & 33 & 18 \\
\hline
\end{tabular}


It is worth mentioning that in this method, low MDLs and MQLs were achieved for antibiotics, even though low sample volumes were used for sample preconcentration. By reducing the sample volume of complex samples such as river water, matrix effects may be decreased. In fact, MDLs and MQLs obtained in this study were comparable to those obtained by USEPA 1694 method where a bigger volume had to be loaded in the SPE cartridge [19]. The proposed analytical method showed satisfactory performance characteristics in terms of linearity, repeatability, reproducibility, accuracy and sensitivity (Table 4).

According to the results shown in Table 5, only the Pedras River (lower side) showed the presence of antimicrobial substances, from both tetracycline class (oxytetracycline), and sulfonamide class (sulfamethoxazole). All other 12 studied compounds were not detected. Failure to identify the substances sought in the Parado River may be related to the shortage of location farms animal (cattle and poultry production) where the river flows. It was also observed that, only in the lower region of the Pedras River, substances were identified, probably due to be in the low region of reduced stream flow of the rivers, facilitating the accumulation of substances. Water samples were collected during three consecutive Sundays and variations in substance concentrations present in the samples collected in the morning and in the afternoon should be related both to management practice and weather conditions.

Sulfamethoxazole is a drug of sulfonamide class and is widely used in human and veterinary medicine. Sulfamethoxazole was detected in the Pedras River at concentrations up to $467.0 \mathrm{ng} \cdot \mathrm{L}^{-1}$. Figure 2 shows MRM chromatograms of a contaminated water sample with a concentration of sulfamethoxazole estimated at 467.0 $\mathrm{ng} \cdot \mathrm{L}^{-1}$, above the MQL of the proposed method. The presence of sulfamethoxazole was verified in four samples in the lower side of the Pedras River, in a total of six samples collected, having a frequency of $67 \%$ of contamination (Table 5).

Sulfamethoxazole is an indicative substance, expected to be present in groundwater which is influenced by wastewater, being relatively polar and persistent [26], according to one study about the environmental occurrence of pharmaceutical products in surface water and WWTP influents and effluents that has been performed in the frame of the project KNAPPE-Knowledge and Need Assessment on Pharmaceutical Products in Environmental Waters funded by the European Commission within the 6th Framework Programme [26] [27].

Table 4. Performance data for pharmaceuticals in surface waters.

\begin{tabular}{|c|c|c|c|c|c|c|c|}
\hline Compound & $\begin{array}{c}\text { \% Recovery }^{*} \\
\text { EPA } 1694 \\
\text { method } \\
( \pm \text { RSD) }\end{array}$ & $\begin{array}{c}\% \text { Recovery }^{* *} \\
\text { proposed } \\
\text { Method } \\
( \pm \text { RSD })(n=3)\end{array}$ & $\begin{array}{l}\mathbf{R}^{2} \text { proposed } \\
\text { method }\end{array}$ & $\begin{array}{l}\text { MDL proposed } \\
\text { method } \\
\left(\mathrm{ng} \cdot \mathrm{L}^{-1}\right)\end{array}$ & $\begin{array}{c}\text { MQL } \\
\text { proposed } \\
\text { method } \\
\left(\mathrm{ng} \cdot \mathrm{L}^{-1}\right)\end{array}$ & $\begin{array}{c}\text { Repeatability } \\
\text { preliminary } \\
( \pm \text { RSD) }(n=3)\end{array}$ & $\begin{array}{c}\text { Reproducibility } \\
\text { preliminary } \\
( \pm \text { RSD) }(n=6)\end{array}$ \\
\hline Chlortetracycline & 95 (23) & 57 (29) & 0.9941 & 3.05 & 10.16 & 11 & 29 \\
\hline Demeclocycline & $137(2)$ & $66(5)$ & 0.9973 & 1.22 & 4.08 & 4 & 5 \\
\hline Doxycycline & $120(1)$ & $92(8)$ & 0.9889 & 1.99 & 6.62 & 11 & 11 \\
\hline Metacycline & - & $84(9)$ & 0.9928 & 1.51 & 5.03 & 6 & 10 \\
\hline Oxytetracycline & $149(4)$ & 87 (4) & 0.9941 & 6.09 & 20.31 & 3 & 6 \\
\hline Tetracycline & $125(4)$ & 78 (12) & 0.9930 & 7.17 & 23.90 & 5 & 13 \\
\hline Dapsone & - & 77 (12) & 0.9958 & 0.67 & 2.24 & 3 & 14 \\
\hline Sulfacetamide & - & $88(5)$ & 0.9933 & 1.63 & 5.42 & 6 & 6 \\
\hline Sulfadimethoxine & $87(3)$ & $92(3)$ & 0.9944 & 0.57 & 1.90 & 4 & 5 \\
\hline Sulfamerazine & $91(1)$ & $89(8)$ & 0.9965 & 0.52 & 1.73 & 6 & 9 \\
\hline Sulfamethazine & $101(6)$ & $88(5)$ & 0.9948 & 0.71 & 2.36 & 2 & 6 \\
\hline Sulfamethoxazole & $88(4)$ & $88(8)$ & 0.9974 & 2.62 & 8.74 & 8 & 9 \\
\hline Sulphaquinoxaline & - & $90(10)$ & 0.9927 & 3.14 & 10.45 & 2 & 13 \\
\hline Sulfathiazole & 77 (4) & $80(3)$ & 0.9952 & 3.12 & 10.41 & 2 & 4 \\
\hline
\end{tabular}

${ }^{*}$ Range $=15$ to $75 \mathrm{ng} \cdot \mathrm{L}^{-1}$, depending on the analyte; ${ }^{* *}$ At $100 \mathrm{ng} \cdot \mathrm{L}^{-1}$. 
Table 5. Concentration $\left(\mathrm{ng} \cdot \mathrm{L}^{-1}\right)$ of studied pharmaceutical drugs in river surface waters from Lidice.

\begin{tabular}{|c|c|c|c|c|c|}
\hline \multicolumn{6}{|c|}{ Concentration (ng $\left.\cdot \mathrm{L}^{-1}\right)$} \\
\hline Compound & $\begin{array}{l}\text { "Pedras River } \\
\text { (lower side) }\end{array}$ & $\begin{array}{l}\text { "Pedras River } \\
\text { (upper side) }\end{array}$ & $\begin{array}{l}\text { "Parado River } \\
\text { (upper side) }\end{array}$ & $\begin{array}{l}\text { "Parado River } \\
\text { (lower side) }\end{array}$ & $\begin{array}{c}\text { Contaminated } \\
\text { samples (\%) }\end{array}$ \\
\hline Chlortetracycline & $<\mathrm{MDL}$ & $<\mathrm{MDL}$ & $<\mathrm{MDL}$ & $<\mathrm{MDL}$ & 0 \\
\hline Demeclocycline & $<\mathrm{MDL}$ & $<\mathrm{MDL}$ & $<\mathrm{MDL}$ & $<\mathrm{MDL}$ & 0 \\
\hline Doxycycline & $<\mathrm{MDL}$ & $<\mathrm{MDL}$ & $<\mathrm{MDL}$ & $<\mathrm{MDL}$ & 0 \\
\hline Metacycline & $<\mathrm{MDL}$ & $<\mathrm{MDL}$ & $<\mathrm{MDL}$ & $<\mathrm{MDL}$ & 0 \\
\hline Oxytetracycline & $<$ MDL - 44.1 & $<\mathrm{MDL}$ & $<$ MDL & $<\mathrm{MDL}$ & 67 \\
\hline Tetracycline & $<\mathrm{MDL}$ & $<\mathrm{MDL}$ & $<\mathrm{MDL}$ & $<\mathrm{MDL}$ & 0 \\
\hline Dapsone & $<\mathrm{MDL}$ & $<\mathrm{MDL}$ & $<\mathrm{MDL}$ & $<\mathrm{MDL}$ & 0 \\
\hline Sulfacetamide & $<\mathrm{MDL}$ & $<\mathrm{MDL}$ & $<\mathrm{MDL}$ & $<\mathrm{MDL}$ & 0 \\
\hline Sulfadimethoxin & $<\mathrm{MDL}$ & $<\mathrm{MDL}$ & $<\mathrm{MDL}$ & $<\mathrm{MDL}$ & 0 \\
\hline Sulfamerazine & $<\mathrm{MDL}$ & $<\mathrm{MDL}$ & $<\mathrm{MDL}$ & $<\mathrm{MDL}$ & 0 \\
\hline Sulfamethazine & $<\mathrm{MDL}$ & $<\mathrm{MDL}$ & $<\mathrm{MDL}$ & $<\mathrm{MDL}$ & 0 \\
\hline Sulfamethoxazole & $>$ MDL - 467.0 & $<\mathrm{MDL}$ & $<\mathrm{MDL}$ & $<\mathrm{MDL}$ & 67 \\
\hline Sulphaquinoxaline & $<\mathrm{MDL}$ & $<\mathrm{MDL}$ & $<\mathrm{MDL}$ & $<\mathrm{MDL}$ & 0 \\
\hline Sulfathiazole & $<\mathrm{MDL}$ & $<\mathrm{MDL}$ & $<\mathrm{MDL}$ & $<\mathrm{MDL}$ & 0 \\
\hline
\end{tabular}

This substance has been found worldwide in several different types of water. The highest antibiotic concentrations were detected at five points located along the Atibaia River watershed, in the State of São Paulo, Brazil. At these sampling point, sulfamethoxazole presented a maximum concentration of $109 \mathrm{ng} \cdot \mathrm{L}^{-1}$ [25]. In Spain, sulfamethoxazole was detected at a maximum concentration of $119 \mathrm{ng} \cdot \mathrm{L}^{-1}$, in the Llobregat River and in the rivers in the area of Girona [15] [27] [28]. In Germany, sulfamethoxazole was determined with a concentration of $0.48 \mu \mathrm{g} \cdot \mathrm{L}^{-1}$, in the Lutter River, in Bielefeld [22]. Sulfamethoxazole has been frequently detected in other studies of pharmaceuticals, in surface waters from the rivers in USA at concentrations up to $150 \mathrm{ng} \cdot \mathrm{L}^{-1}$ [29]-[33].

Studies conducted by Kasprzyk-Hordern et al. [34] in the Taff River, United Kingdom, and in the Warta River, Poland, showed that sulfamethoxazole was determined with a concentration between 26 and $60 \mathrm{ng} \cdot \mathrm{L}^{-1}$. The maximum value in surface waters for sulfamethoxazole in Portugal was $8.0 \mathrm{ng} \cdot \mathrm{L}^{-1}$ in the Tejo and Zêzere rivers [14]. High concentrations of sulfamethoxazole were detected in the Nairobi River, Nigeria, and were related to the large amounts of consumption of this antibiotic in the country. The maximum concentration found in this river was $20 \mu \mathrm{g} \cdot \mathrm{L}^{-1}$ [35].

Oxytetracycline is a broad spectrum antibiotic with a long history in veterinary medicine for the treatment and control of a wide variety of bacterial infections. A previous work accomplished in our laboratory had demonstrated that oxytetracycline was the most frequently detected substance from tetracycline group in milk samples in the metropolitan area of Rio de Janeiro [5]. The maximum concentration of oxytetracycline detected in the Pedras River was $44.1 \mathrm{ng} \cdot \mathrm{L}^{-1}$. Figure 2 shows MRM chromatograms of a contaminated water sample with a concentration of oxytetracyline estimated at $44.1 \mathrm{ng} \cdot \mathrm{L}^{-1}$, above the MQL of the proposed method. Oxytetracycline was present in four samples in the lower side of the Pedras River, in a total of six samples collected, having a frequency of $67 \%$ of contamination (Table 5).

Tetracyclines can enter the aquatic environment via effluent discharge of sewage treatment plants (STPs), agricultural runoff, or disposal of unused drugs. In China, in surface water samples, oxytetracycline was detected at a level of $2.2 \mathrm{ng} \cdot \mathrm{L}^{-1}[36]$.

Tetracyclines were detected in river waters around the world in a much lesser extent than sulfonamides.

\section{Conclusions}

The presence of pharmaceuticals in the environment raises many questions about the risk to the environment and 

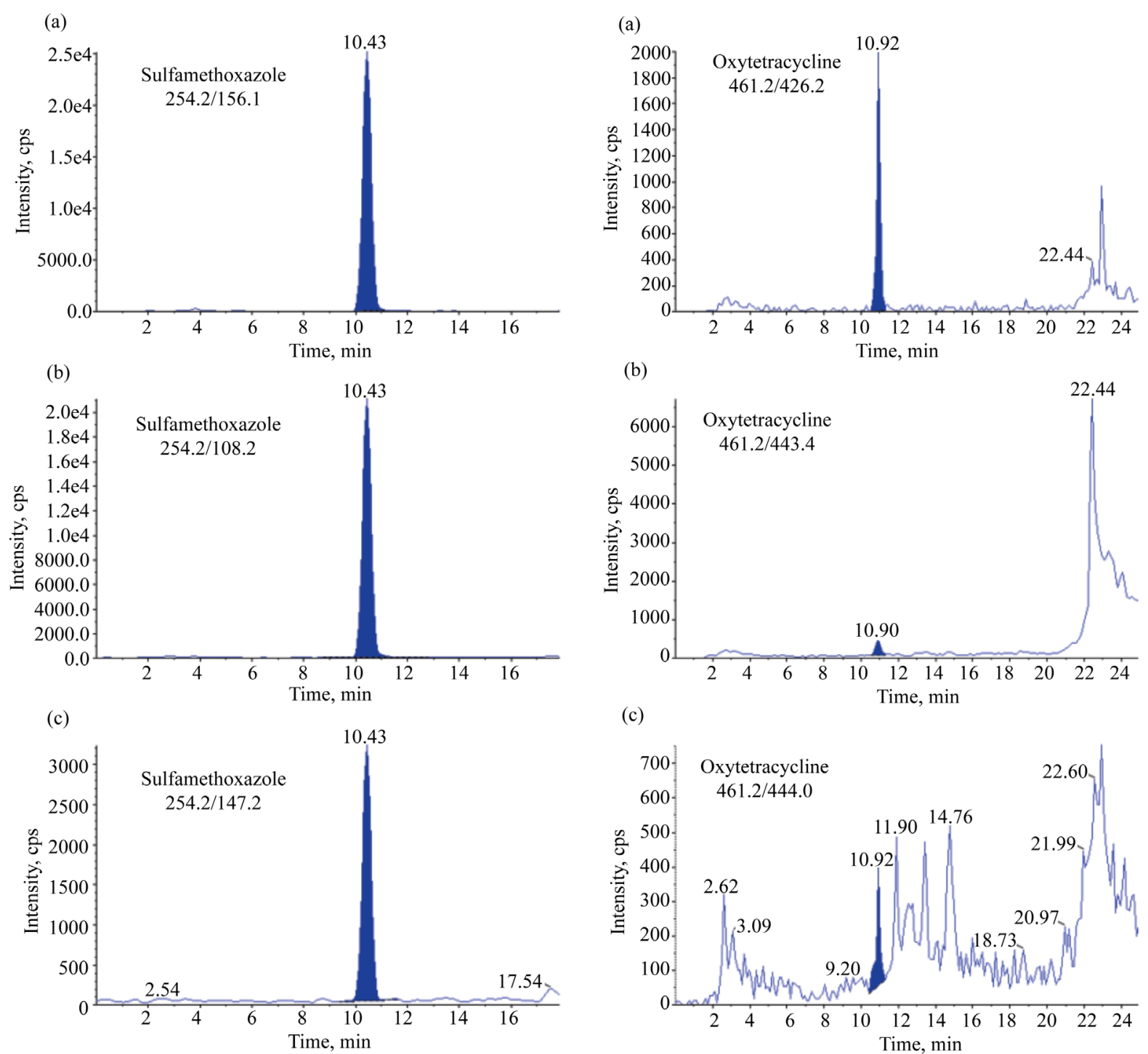

Figure 2. MRM chromatograms of a contaminated water sample with a concentration of sulfamethoxazole estimated at $467.0 \mathrm{ng} \cdot \mathrm{L}^{-1}$ and of a contaminated water sample with a concentration of oxytetracycline estimated at $44.1 \mathrm{ng} \cdot \mathrm{L}^{-1}$ (a) $1^{\mathrm{st}}$ transition; (b) $2^{\text {nd }}$ transition; (c) $3^{\text {rd }}$ transition.

human health. The occurrence of antimicrobials in the environment, especially in aquatic systems, has recently become a matter of concern. This study investigated the presence of sulfonamide and tetracycline residues in river water samples from Lidice District of Rio Claro, in the State of Rio de Janeiro, Brazil. The results confirmed the presence of sulfamethoxazole and oxytetracycline in one of the two rivers studied: the Pedras River. The compounds were present at the $\mathrm{ng} \cdot \mathrm{L}^{-1}$ level, with a maximum concentration of $467.0 \mathrm{ng} \cdot \mathrm{L}^{-1}$ for sulfamethoxazole and $44.1 \mathrm{ng} \cdot \mathrm{L}^{-1}$ for oxytetracycline.

The results presented of the proposed method for sulfonamides and tetracyclines were satisfactory and indicated that the approach was very promising for antibiotics determination in surface water. Therefore, the validation of methodology will be performed according to protocol for EPA approval of new methods.

The most important issues to worry about, related to the presence of these compounds in the environment, are the possibility that they may exert ecotoxicological effects on non-target organisms and that they may possibly enter into the human food supply via the water cycle.

Through this background, it is highly troubling that in Brazil there is not yet legislation considering drugs as pollutants, and the possible effects of their residues on health have not been evaluated by WHO so far. 


\section{Acknowledgements}

The authors thank the Brazilian National Coordination for the Improvement of Higher Education Personnel (CAPES) for financial support. We also thank Eduardo Gomes Rodrigues de Sousa and Patrícia Condé Lima for revising the manuscript.

\section{References}

[1] Regitano, J.B. and Leal, R.M.P. (2010) Comportamento e impacto ambiental de antibióticos usados na produção animal brasileira. Revista Brasileira de Ciência do Solo, 34, 601-616. http://dx.doi.org/10.1590/S0100-06832010000300002

[2] Spisso, B.F., de Oliveira e Jesus, A.L., de Araújo Júnior, M.A.G. and Monteiro, M.A. (2007) Validation of a HighPerformance Liquid Chromatographic Method with Fluorescence Detection for the Simultaneous Determination of Tetracyclines Residues in Bovine Milk. Analytica Chimica Acta, 581, 108-117. http://dx.doi.org/10.1016/j.aca.2006.08.004

[3] Spisso, B.F., Araújo Júnior, M.A.G., Monteiro, M.A., Lima, A.M.B., Pereira, M.U., Luiz, R.A. and Nóbrega, A.W. (2009) A Liquid Chromatography-Tandem Mass Spectrometry Confirmatory Assay for the Simultaneous Determination of Several Tetracyclines in Milk Considering Keto-Enol Tautomerism and Epimerization Phenomena. Analytica Chimica Acta, 656, 72-84. http://dx.doi.org/10.1016/j.aca.2009.10.012

[4] Spisso, B.F., Ferreira, R.G., Pereira, M.U., Monteiro, M.A., Cruz, T.A., Costa, R.P., Lima, A.M.B. and Nóbrega, A.W. (2010) Simultaneous Determination of Polyether Ionophores, Macrolides and Lincosamides in Hen Eggs by Liquid Chromatography-Electrospray Ionization Tandem Mass Spectrometry Using a Simple Solvent Extraction. Analytica Chimica Acta, 682, 82-92. http://dx.doi.org/10.1016/j.aca.2010.09.047

[5] Spisso, B.F., Monteiro, M.A., Pereira, M.U., Ferreira, R.G., Costa, R.P., Cruz, T.A., Lima, A.M.B. and Nóbrega, A.W. (2010) Pilot Survey of Commercial Pasteurized Milk Consumed in the Metropolitan Area of Rio de Janeiro, Brazil, for Tetracyclines Residues, including the 4-Epimers of Oxytetracycline, Tetracycline and Chlortetracycline. Food Additives \& Contaminants: Part B, 3, 220-227. http://dx.doi.org/10.1080/19393210.2010.531401

[6] Ferreira, R.G., Spisso, B.F., Hora, I.M.C., Monteiro, M.A., Pereira, M.U., Costa, R.P. and Carlos, B.S. (2012) Panorama da ocorrência de resíduos de medicamentos veterinários em leite no Brasil. SAN, 19, 30-49.

[7] Santos, J.R.M.P. (2015) Desenvolvimento de metodologias para a determinação de sulfonamidas em leite UHT. Dissertation, Oswaldo Cruz Foundation, Rio de Janeiro.

[8] Lipinski, C.A., Lombardo, F., Dominy, B.W. and Feeney, P.J. (1997) Experimental and Computational Approaches to Estimate Solubility and Permeability in Drug Discovery and Development Settings. Advanced Drug Delivery Reviews, 23, 3-25. http://dx.doi.org/10.1016/S0169-409X(96)00423-1

[9] Gbylik-Sikorska, M., Posyniak, A., Sniegocki, T. and Zmudzki, J. (2015) Liquid Chromatography-Tandem Mass Spectrometry Multiclass Method for the Determination of Antibiotics Residues in Water Samples from Water Supply Systems in Food-Producing Animal Farms. Chemosphere, 119, 8-15. http://dx.doi.org/10.1016/j.chemosphere.2014.04.105

[10] Heberer, T. (2002) Occurrence, Fate, and Removal of Pharmaceutical Residues in the Aquatic Environment: A Review of Recent Research Data. Toxicology Letters, 131, 5-17. http://dx.doi.org/10.1016/S0378-4274(02)00041-3

[11] Bila, D.M. and Dezotti, M. (2003) Antibióticos no meio ambiente. Quim Nova, 26, 523-530. http://dx.doi.org/10.1590/S0100-40422003000400015

[12] Kümmerer, K. (2003) Significance of Antibiotics in the Environment. Journal of Antimicrobial Chemotherapy, 52, 5-7. http://dx.doi.org/10.1093/jac/dkg293

[13] Sanderson, H., Brain, R.A., Johnson, D.J., Wilson, C.J. and Solomon, K.R. (2004) Toxicity Classification and Evaluation of Four Pharmaceuticals Classes: Antibiotics, Antineoplastics, Cardiovascular, and Sex Hormones. Toxicology, 203, 27-40. http://dx.doi.org/10.1016/j.tox.2004.05.015

[14] Gaffney, V.J., Cardoso, V.V., Rodrigues, A., Ferreira, E., Benoliel, M.J. and Almeida, C.M.M. (2014) Análise de fármacos em águas por SPE-UPLC-ESI-MS/MS. Quim Nova, 3, 138-149. http://dx.doi.org/10.1590/S0100-40422014000100023

[15] Gros, M., Rodríguez-Mozaz, S. and Barceló, D. (2012) Fast and Comprehensive Multi-Residue Analysis of a Broad Range of Human and Veterinary Pharmaceuticals and Some of Their Metabolites in Surface and Treated Waters by Ultra-High-Performance Liquid Chromatography Coupled to Quadrupole-Linear Ion Trap Tandem Mass Spectrometry. Journal of Chromatography A, 1248, 104-121. http://dx.doi.org/10.1016/j.chroma.2012.05.084

[16] Crestana, G.B. and Silva, J.H. (2011) Antibióticos residuais: Panorama de um cenário negligenciado. REID, 9, 55-65.

[17] Gros, M., Petrovic, M. and Barceló, D. (2006) Multi-Residue Analytical Methods Using LC-Tandem MS for the De- 
termination of Pharmaceuticals in Environmental and Wastewater Samples: A Review. Analytical and Bioanalytical Chemistry, 386, 941-952. http://dx.doi.org/10.1007/s00216-006-0586-Z

[18] Prestes, O.D., Martins, M.L., Friggi, C.A., Munaretto, J.S., Adaime, M.B. and Zanella, R. (2013) O estado da arte na determinação de resíduos de medicamentos veterinários em alimentos de origem animal empregando técnicas cromatográficas acopladas à espectrometria de massas. Quim Nova, 36, 697-710. http://dx.doi.org/10.1590/S0100-40422013000500015

[19] USEPA (2007) Method 1694: Pharmaceuticals and Personal Care Products in Water, Soil, Sediment, and Biosolids by HPLC/MS/MS.

[20] Rio Claro Geography (2015) http://www.achetudoeregiao.com.br/rj/Rio_Claro/localizacao.htm

[21] Verzegnassi, L., Savoy-Perroud, M.C. and Stadler, R.H. (2002) Application of Liquid Chromatography-Electrospray Ionization Tandem Mass Spectrometry to the Detection of 10 Sulfonamides in Honey. Journal of Chromatography A, 977, 77-87. http://dx.doi.org/10.1016/S0021-9673(02)01341-9

[22] Hirsch, R., Ternes, T.A., Haberer, K., Mehlich, A., Ballwanz, A.F. and Kratz, K. (1998) Determination of Antibiotics in Different Water Compartments via Liquid Chromatography-Electrospray Tandem Mass Spectrometry. Journal of Chromatography A, 815, 213-223. http://dx.doi.org/10.1016/S0021-9673(98)00335-5

[23] Yang, S., Cha, J. and Carlson, K. (2005) Simultaneous Extraction and Analysis of 11 Tetracycline and Sulfonamide Antibiotics in Influent and Effluent Domestic Wastewater Ionization Tandem Mass Spectrometry. Journal of Chromatography A, 1097, 40-53. http://dx.doi.org/10.1016/j.chroma.2005.08.027

[24] Ferrer, I., Zweigenbaum, J.A. and Thurman, E.M. (2010) Analysis of 70 Environmental Protection Agency Priority Pharmaceuticals in Water by EPA Method 1694. Journal of Chromatography A, 1217, 5674-5686. http://dx.doi.org/10.1016/j.chroma.2010.07.002

[25] Locatelli, M.A.F., Sodre, F.F. and Jardim, W.F. (2011) Determination of Antibiotics in Brazilian Surface Waters Using Liquid Chromatography-Electrospray Tandem Mass Spectrometry. Archives of Environmental Contamination and Toxicology, 60, 385-393. http://dx.doi.org/10.1007/s00244-010-9550-1

[26] KNAPPE (2008) Knowledge and Need Assessment on Pharmaceutical Products in Environmental Waters. Sixth Framework Programme.

[27] López-Roldán, R., Alda, M.L., Gros, M., Petrovic, M., Martín-Alonso, J. and Barceló, D. (2010) Advanced Monitoring of Pharmaceuticals and Estrogens in the Llobregat River Basin (Spain) by Liquid Chromatography-Triple Quadrupole-Tandem Mass Spectrometry in Combination with Ultra Performance Liquid Chromatography-Time of FlightMass Spectrometry. Chemosphere, 80, 1337-1344. http://dx.doi.org/10.1016/j.chemosphere.2010.06.042

[28] Gros, M., Rodríguez-Mozaz, S. and Barceló, D. (2013) Rapid Analysis of Multiclass Antibiotic Residues and Some of Their Metabolites in Hospital, Urban Wastewater and River Water by Ultra-High-Performance Liquid Chromatography Coupled to Quadrupole-Linear Ion Trap Tandem Mass Spectrometry. Journal of Chromatography A, 1292, 173188. http://dx.doi.org/10.1016/j.chroma.2012.12.072

[29] Kolpin, D.W., Furlong, E.T., Meyer, M.T., Thurman, E.M., Zaugg, S.D., Barber, L.B. and Buxton, H.T. (2002) Pharmaceuticals, Hormones, and Other Organic Wastewater Contaminants in US Streams, 1999-2000: A National Reconnaissance. Environmental Science \& Technology, 36, 1202-1211. http://dx.doi.org/10.1021/es011055j

[30] Kolpin, D.W., Skopec, M., Meyer, M.T., Furlong, E.T. and Zaugg, S.D. (2004) Urban Contribution of Pharmaceuticals and Other Organic Wastewater Contaminants to Streams during Differing Flow Conditions. Science of the Total Environment, 328, 119-130. http://dx.doi.org/10.1016/j.scitotenv.2004.01.015

[31] Vanderford, B.J., Pearson, R.A., Rexing, D.J. and Snyder, S.A. (2003) Analysis of Endocrine Disruptors, Pharmaceuticals, and Personal Care Products in Water Using Liquid Chromatography/Tandem Mass Spectrometry. Analytical Chemistry, 75, 6265-6274. http://dx.doi.org/10.1021/ac034210g

[32] Conley, J.M., Symes, S.J., Schorr, M.S. and Richards, S.M. (2008) Spatial and Temporal Analysis of Pharmaceutical Concentrations in the Upper Tennessee River Basin. Chemosphere, 73, 1178-1187. http://dx.doi.org/10.1016/j.chemosphere.2008.07.062

[33] Wang, C., Shi, H., Adams, C.D., Gamagedara, S., Stayton, I., Timmons, T. and Ma, Y. (2011) Investigation of Pharmaceuticals in Missouri Natural and Drinking Water Using High Performance Liquid Chromatography-Tandem Mass Spectrometry. Water Research, 45, 1818-1828. http://dx.doi.org/10.1016/j.watres.2010.11.043

[34] Kasprzyk-Hordern, B., Dinsdale, R.M. and Guwy, A.J. (2007) Multi-Residue Method for the Determination of Basic/ Neutral Pharmaceuticals and Illicit Drugs in Surface Water by Solid-Phase Extraction and Ultra Performance Liquid Chromatography-Positive Electrospray Ionisation Tandem Mass Spectrometry. Journal of Chromatography A, 1161, 132-145. http://dx.doi.org/10.1016/j.chroma.2007.05.074

[35] Jia, A., Xiao, Y., Hu, J., Asami, M. and Kunikane, S. (2009) Simultaneous Determination of Tetracyclines and Their Degradation Products in Environmental Waters by Liquid Chromatography-Electrospray Tandem Mass Spectrometry. 
Journal of Chromatography A, 1216, 4655-4662. http://dx.doi.org/10.1016/j.chroma.2009.03.073

[36] Koreje, K.O., Demeestere, K., Wispelaere, P., Vergeynst, L., Dewulf, J. and Langenhove, H.V. (2012) From Multiresidue Screening to Target Analysis of Pharmaceuticals in Water: Development of a New Approach Based on Magnetic Sector Mass Spectrometry and Application in the Nairobi River Basin, Kenya. Science of the Total Environment, 437, 153-164. http://dx.doi.org/10.1016/j.scitotenv.2012.07.052 